Запорізький державний медичний університет, м. Запоріжжя

\title{
ОСОБЛИВОСТІ АУДИТОРНОЇ ТА ПОЗААУДИТОРНОЇ РОБОТИ СТУДЕНТІВ СТОМАТОЛОГІЧНОГО ПРОФІЛЮ ПІД ЧАС ВИВЧЕННЯ ПАТОМОРФОЛОГІЇ В ЗАПОРІЗЬКОМУ ДЕРЖАВНОМУ МЕДИЧНОМУ УНIВЕРСИТЕТІ
}

\author{
Zaporizhzhia State Medical University \\ SOME FEATURES OF STOMATOLOGICAL PROFILE STUDENTS \\ IN-CLASS AND OUT-OF-CLASS WORK DURING STUDY OF \\ PATHOMORPHOLOGY IN ZAPORIZHZHIA STATE \\ MEDICAL UNIVERSITY
}

\begin{abstract}
Мета роботи - висвітлення досвіду та ефективності проведення практичних занять з патоморфології у студентів 2 та 3 курсів стоматологічного профілю навчання у Запорізькому державному медичному університеті у 2015-2018 навчальних роках.

Основна частина. На основі аналізу поточної успішності студентів, а також результатів складання тестового іспиту з патоморфології була наведена оцінка ефективності аудиторної та позааудиторної роботи студентів із навчальними практикумами, зміст яких відповідає навчальній програмі з дисципліни і враховує специфіку підготовчого рівня студентів стоматологічного профілю.

Висновок. Використання студентами спеціально розроблених практикумів під час аудиторної та позааудиторної роботи $\epsilon$ доцільним для реалізації комплексного, найбільш оптимального алгоритму викладання загальної патоморфології та спеціальної патоморфології, позитивно схвалюється студентами та підвищує рівень їх підготовки для складання державного іспиту “Крок-1”.
\end{abstract}

Ключові слова: патоморфологія; стоматологічний профіль; навчальні практикуми.

The aim of the work - to cover the experience and effectiveness of conducting practical classes on Pathomorphology in the 2nd and 3rd course stomatological profile students in Zaporizhzhia State Medical University in 2015-2018 academic years.

The main body. According to current academic performance and test exam on Pathomorphology result analysis, an estimation of efficiency of in-class and out-of-class students' work with educational protocols, adapted to discipline curriculum is given.

Conclusion. Using of student protocols during in-class and out-of-class work is appropriate for the implementation of a comprehensive, most optimal algorithm for teaching Pathomorphology, and is positively endorsed by students during questionnaires, increases the level of students' preparation for state exam Krok-1.

Key words: pathomorphology; stomatological profile; educational protocols.

Вступ. Дисципліна “Патоморфологія”, яка викладається на кафедрі патологічної анатомії і судової медицини Запорізького державного медичного університету (ЗДМУ), є однією з тих, без засвоєння якої складно уявити собі формування майбутнього повноцінного клініциста - фахівця лікувального, діагностичного профілю або лікаря-стоматолога [1]. Патоморфологія як дисципліна за рік вивчення дозволяє сформувати у студентів достатній рівень клінічного мислення, який необхідний для більш ефективного засвоєння нових клінічних дисциплін на наступних етапах навчан-

(c) Т. В. Шулятнікова ня [2]. П'ятирічна навчальна програма стоматологічного профілю істотно відрізняється за змістом, тому, починаючи з першого курсу, студенти мають вивчати окремі дисципліни за дещо скороченою програмою, а деякі предмети, що вивчаються на інших медичних факультетах, і зовсім відсутні в освітній програмі. Серед іншого патоморфологію студенти стоматологічного профілю починають вивчати на другому курсі і закінчують на третьому: у 4-му семестрі - загальну патоморфологію, у 5-му спеціальну патоморфологію. Варто зауважити, що на другому курсі навчання їх базові знання з медикобіологічних дисциплін виявляються недостатніми 
для оптимального сприйняття нової, часто вузькоспеціалізованої інформації клінічного толку порівняно зі студентами інших медичних факультетів. Даний факт, а також більш низький рівень мотивації студентів стоматологічного профілю в детальному вивченні позащелепно-лицьової соматичної патології пояснює істотні труднощі глибинного розуміння патоморфології загальнопатологічних процесів і нозологій. 3 іншого боку, крім необхідності у вихованні нових висококласних фахівців стоматологічної сфери медицини, які зобов’язані мати чіткі уявлення про усі основні патологічні стани організму, також метою роботи зі студентами є підготовка їх до складання державного іспиту “Крок-1”, який на даному етапі є невід’ємною частиною вищої медичної освіти [3]. Варто відзначити, що, з огляду на досвід минулих років, набір задач у тестовій базі “Крок-1” з патоморфології для студентів стоматологічного профілю за рівнем складності, переліком патологій не надто відрізняється від ситуаційних завдань, що пропонуються для інших медичних факультетів. Крім того, в наборі тестів для стоматологічного напрямку передбачений цілий ряд завдань, присвячених виключно стоматологічній проблематиці, що розширює перелік вимог до теоретичної підготовки студентів. Таким чином, студенти стоматологічного напрямку зобов’язані докладати більші зусилля і мати високий рівень мотивації для засвоєння дисципліни, щоб у результаті не тільки показувати гідний рівень знань під час навчання, а й успішно складати державний іспит “Крок-1”.

Вищевказані особливості підготовки і вимоги до сучасних лікарів диктують необхідність у створенні особливих, адаптованих умов навчального процесу та розробці спеціальних навчальних матеріалів, які могли б оптимізувати самопідготовку та аудиторну роботу студентів i, отже, спростити шляхи досягнення кінцевих цілей навчання [4].

Мета роботи - висвітлення досвіду та ефективності проведення практичних занять з патоморфології у студентів 2 та 3 курсів стоматологічного профілю навчання у ЗДМУ у 2015-2018 навчальних роках.

Основна частина. Дослідження особливостей та ефективності навчального процесу в ході вивчення патоморфології було проведено в контингенті вітчизняних студентів 2 і 3 курсів стоматологічного профілю (III медичний факультет) ЗДМУ 3 2015-2016 по 2017-2018 навчальні роки. За досліджуваний період проаналізовано 2 потоки по
60 студентів (у цілому 120 осіб). Кожен з потоків починав вивчення дисципліни на 2 курсі навчання (4 семестр, загальна патоморфологія), закінчував на 3-му (5 семестр, курс спеціальної патоморфологіï). Після здачі підсумкового контролю “Модуль-2” студенти складали тестовий іспит по всій дисципліні, ситуаційні задачі якого були запозичені з загальнодержавної тренінгової тестової бази “Крок-1" для стоматологічного профілю. Таким чином, було виділено 2 групи спостереження: студенти, які пройшли повний курс вивчення патоморфології 3 весняного семестру 2015-2016 по осінній семестр 2016-2017 навчальних років (група порівняння), та ті, що пройшли повний цикл вивчення з весняного семестру 2016-2017 по осінній семестр 2017-2018 навчальних років (основна група).

Особливістю навчального процесу при вивченні патоморфології студентами III медичного факультету $є$ активне використання на практичних заняттях і під час домашньої самопідготовки навчальних протоколів (практикумів). Вони активно впроваджені в навчальний процес з весняного семестру 2016-2017 навчального року (основна група). Для порівняння, у 2015-2016 навчальному році студентам пропонувалися стандартні методичні рекомендації, оснащені тільки переліком питань для самопідготовки, описанням макро- i мікропрепаратів, а також списком рекомендованої літератури. При цьому у студентів виникала необхідність самостійного оформлення альбомів для замальовки препаратів, що завжди супроводжувалося відсутністю стандартизації в інформаційній наповненості, оформленні та, нарешті, акуратності студентських альбомів. Даний підхід в організації самостійної роботи студентів не дозволяв автоматично акцентувати їх увагу на найбільш важливих для запам'ятовування питаннях на етапі підготовки до заняття.

У структуру нових практикумів входять питання по темі заняття для позааудиторної підготовки студентів із зазначенням рекомендованої літератури, перелік назв макро- і мікропрепаратів із детальним описом патоморфологічних змін у кожному випадку. Ознайомившись із цим під час самопідготовки, в ході заняття студенти мають можливість у бесіді обговорити з викладачем весь комплекс змін в органах і тканинах при патологічних процесах. Набір мультимедійних слайдів із зображеннями макро- i мікропрепаратів до кожного заняття $є$ в наявності в повному обсязі й активно використовується в ході навчального процесу викладачами з огляду на 
достатнє оснащення навчальних кімнат кафедри мультимедійними панелями. Допоміжними посібниками в цьому служать атласи з патологічної анатомії, кафедральний музей мікропрепаратів, набір навчальних мікропрепаратів і студентські мікроскопи. Далі в кожному занятті практикуму передбачені поля для замальовки з монітора панелі або з навчального атласу з патологічної анатомії найбільш важливих для запам’ятовування мікропрепаратів, розглянутих раніше.

Крім вищезазначеного, кожне заняття практикуму забезпечене інформативними таблицями, схемами, малюнками, переліком тестових задач і ситуаційних клінічних завдань по темі заняття для самостійного рішення, а також рядом питань теоретичного плану (визначення, класифікації, ускладнення, етапи морфогенезу патологій та ін.), на які студент повинен детально відповісти під час заняття, до або після нього, письмово заповнивши передбачені для цього поля в протоколі. Треба наголосити, що тестові завдання до кожної теми підбираються таким чином, щоб кожна відображала в собі будьяке з ключових питань заняття. Більшість завдань за своєю суттю є “якірними”, відображають загальні тенденції і містять смислові акценти, які використовуються в тестовій базі “Крок-1” стоматологічного профілю. Рішення тематичних “якірних” тестових завдань, ознайомлення $з$ ключовими, акцентованими питаннями теоретичного плану під час позааудиторної самопідготовки дозволяє студентам після прочитання навчальної літератури, прослуховування лекцій із дисципліни сформувати для себе більш цільне уявлення про дану проблематику, акцентувати увагу на окремих питаннях. Самостійна замальовка препаратів із детальним описом мікроскопічних змін, рукописні відповіді на питання теоретичного плану з подальшим обговоренням цих же питань в усній формі з викладачем на занятті сприяють більшій зацікавленості студентів до предмета, пробудженню творчого підходу до вивчення дисципліни, більш глибокому осмисленню і кращій засвоюваності інформації [5].

\section{Список літератури}

1. Marshall R. Teaching and learning pathology: a critical review of the English literature / R. Marshall, N. Cartwright, K. Mattick // Med. Educ. - 2004. - Vol. 38, No 3. P. 302-313.

2. Гаврилюк А. О. Роль патологічної анатомії в системі медичної освіти та формуванні професійних навичок майбутніх лікарів / А. О. Гаврилюк, Г. М. Галунко,
Аналіз поточної успішності порівнюваних груп, а також результатів здачі ними підсумкового тестового іспиту показав, що студенти основної групи дослідження показали більшу зацікавленість дисципліною, більш високі показники поточної і підсумкової якісної успішності, більш високий середній відсоток результату здачі тестового іспиту 3 дисципліни. Так, кількість студентів, що успішно склали тестовий іспит, в основній групі спостереження виріс на 5,54 \% порівняно з групою порівняння. Також відмічено зростання якісної успішності студентів в основній групі спостереження порівняно з групою 2015-2017 навчального року приріст склав 7,85 \% (72,15 \% і 80 \% відповідно). Результат паперового анкетування студентів основної групи в кінці вивчення дисципліни (за участю 92 \% осіб від повного складу групи) показав, що 87 \% 3 них дали позитивну оцінку і повну задоволеність роботою з навчальними практикумами під час позааудиторної та аудиторної роботи при вивченні патоморфології. Отримані результати не можуть враховувати все різноманіття факторів, що впливають на загальний рівень підготовки студентів, їх мотивацію, здатність вирішувати клінічні завдання. Однак можна стверджувати, що розробка і вдосконалення адаптованих навчально-методичних матеріалів, що містять необхідну акцентуацію і можливість для творчого прояву в процесі самопідготовки і самостійної роботи студентів на заняттях, дозволяє істотно оптимізувати мотиваційну діяльність викладачів під час навчального процесу і підвищити ефективність освітнього процесу.

Висновок. Використання студентами стоматологічного напрямку навчання розроблених навчальних практикумів під час аудиторної і позааудиторної роботи є доцільним для оптимізації комплексного алгоритму викладання загальної патоморфології та спеціальної патоморфології, позитивно схвалюється студентами під час анкетування, стимулює мотивацію студентів до опанування дисципліни i підвищує рівень підготовки студентів для складання державного іспиту “Крок-1”.

Т. М. Король // Проблеми та перспективи вищої медичної школи у розробці та реалізації національної стратегії побудови нової системи охорони здоров'я в Україні на період 2015-2025 рр. : зб. матеріалів навч.-метод. конф., 25 берез. 2015 р. - Вінниця, 2015. - С. 26-27.

3. Жаріков М. Ю. Порівняльний аналіз результатів тестового контролю з анатомії людини студентами ме- 
дичних факультетів 2 та 3 курсів в аспекті підготовки до іспиту “Крок-1” / М. Ю. Жаріков, С. Б. Крамар, Д. І. Назарова // Медична освіта. - 2012. - № 4. С. 41-43.

\section{References}

1. Marshall, R., Cartwright, N., \& Mattick, K. (2004). Teaching and learning pathology: a critical review of the English literature. Medical Education, 38 (3), 302-313.

2. Havryliuk, A.O., Halunko, H.M., \& Korol, T.M. (2015). Rol patolohichnoi anatomii v systemi medychnoi osvity ta formuvanni profesiinykh navychok maibutnikh likariv [The role of pathological anatomy in future doctors' medical education and skills formation]. Navch.-metod. conf "Problemy ta perspektyvy vyshchoi medychnoi shkoly u rozrobtsi ta realizatsii Natsionalnoi stratehii pobudovy novoi systemy okhorony zdorovia v Ukraini na period 2015-2025 rr. Educational and methodological conference "Problems and Prospects of Higher Medical Education in Developing and Implementing a National Strategy of New Health Care System Development in Ukraine for the Period of 2015-2025 years”. (pp. 26-27). Vinnytsia [in Ukrainian].
4. Stahl S. M. Best practices in medical teaching/S. M. Stahl, R. L. Davis. - NY : Cambridge University Press, 2011. -178 p.

5. Захарченко Т. Роль наочності у процесі викладання професійно орієнтованих дисциплін / Т. Захарченко // Вища школа. - 2013. - № 12. - С. 30-38.

3. Zharikov, M.Yu., Kramar, S.B., \& Nazarova, D.I. (2012). Porivnialnyi analiz rezultativ testovoho kontroliu $\mathrm{z}$ anatomii liudyny studentamy medychnykh fakultetiv 2 ta 3 kursiv v aspekti pidhotovky do ispytu Krok-1 [Comparative analysis of the results of human anatomy test control by students of medical faculties of 2 and 3 courses in the aspect of preparation for the exam Krok-1]. Medychna osvita - Medical Education, 4, 41-43 [in Ukrainian].

4. Stahl, S.M., \& Davis, R.L. (2011). Best practices in medical teaching. NY: Cambridge University Press.

5. Zakharchenko, T. (2013). Rol naochnosti u protsesi vykladannia profesiino oriientovanykh dystsyplin [The role of visibility in the teaching of professionally oriented disciplines]. Vyshcha shkola - High School, 12, 30-38 [in Ukrainian]. 